\title{
Resolving the interactions of ocean acidification and temperature on coral calcification media $\mathbf{p H}$
}

\author{
Nicola Allison ${ }^{1}$ (I) Catherine Cole $^{1,4} \cdot$ Chris Hintz $^{2} \cdot$ Ken Hintz $^{3} \cdot$ James Rae $^{1}$. \\ Adrian Finch ${ }^{1}$
}

Received: 1 August 2020/Accepted: 9 August 2021/Published online: 18 August 2021

(C) The Author(s) 2021

\begin{abstract}
Ocean acidification typically reduces the calcification rates of massive Porites spp. corals, but increasing seawater temperatures (below the stress and bleaching threshold) can offset this effect. Here, we use $\delta^{11} \mathrm{~B}$ to reconstruct the $\mathrm{pH}$ of the calcification media $\left(\mathrm{pH}_{\mathrm{ECM}}\right)$ used to precipitate the skeleton in poritid corals cultured over a range of seawater $\mathrm{pCO}_{2}$ and at $25{ }^{\circ} \mathrm{C}$ and $28{ }^{\circ} \mathrm{C}$. Increasing temperature had no significant effect on $\mathrm{pH}_{\mathrm{ECM}}$ at high $\mathrm{pCO}_{2}$ although corals increased their calcification rates. $\mathrm{pH}_{\mathrm{ECM}}$ was reduced at $28{ }^{\circ} \mathrm{C}$ compared to $25{ }^{\circ} \mathrm{C}$ at low seawater $\mathrm{pCO}_{2}$, although calcification rates remained constant. Increasing calcification rates could reflect the positive influence of temperature on aragonite precipitation rate, an increase in calcification media saturation state or a change in the concentration/behaviour of the skeletal organic matrix. The two temperatures utilized in this study were within the seasonal range at the coral collection site and do not represent a heat stress scenario. Increasing seawater temperatures may promote calcification in some corals in the future but are unlikely to benefit the majority
\end{abstract}

Topic Editor Morgan S. Pratchett

Nicola Allison

na9@st-andrews.ac.uk

1 School of Earth and Environmental Sciences, University of St. Andrews, St. Andrews KY16 9AL, UK

2 Department of Marine and Environmental Sciences, Savannah State University, Savannah, GA, USA

3 Department of Electrical and Computer Engineering, George Mason University, Fairfax, VA, USA

4 Present Address: Now At Centre of Science Communication, University of Otago, Dunedin 9016, New Zealand of corals, which are already living close to their maximum thermal tolerance limits.

Keywords Dissolved inorganic carbon - Coral . Calcification $\cdot \delta^{11} \mathrm{~B} \cdot$ Calcification media $\cdot$ Ocean acidification

\section{Introduction}

Coral reefs are amongst the most diverse ecosystems and support the livelihoods of millions of people (Cinner 2014). Rising atmospheric $\mathrm{CO}_{2}$ is increasing the temperatures and decreasing the $\mathrm{pH}$ of most surface seawaters (IPCC 2014). Understanding how these changes affect the accretion of aragonite skeletons by the tropical corals that underpin reef structures is key to predicting the future of coral reefs. Coral calcification is usually reduced at lower seawater $\mathrm{pH}$ (Erez et al. 2011), but massive Porites spp. corals, important reef-building species in the Indo-Pacific (Veron 1993), appear to be relatively resilient to ocean acidification (Fabricius et al. 2011; Crook et al. 2012). In culture studies, the calcification and linear extension rates of this genus can be reduced at high seawater $\mathrm{pCO}_{2}$ (Cole et al. 2016), but this suppression can be mitigated by increases in seawater temperature below the temperature stress threshold (Anthony et al. 2008; Edmunds 2012; Cole et al. 2018). The response of calcification to temperature change is seawater $\mathrm{pCO}_{2}$ dependent (Anthony et al. 2008; Cole et al. 2018; Edmunds 2012). The precipitation rate of synthetic (inorganic) aragonites is positively correlated with temperature (Burton and Walter 1987). However, the coral calcification increase observed by Cole et al. (2018) at high $\mathrm{pCO}_{2}$ is much higher than that predicted from synthetic aragonites, while at low $\mathrm{pCO}_{2}$, the change in coral 
calcification rate is lower than that predicted from synthetic aragonites. Understanding how temperature and seawater $\mathrm{pCO}_{2}$ interact to drive these changes in coral calcification is a goal of the current study.

The coral skeleton forms from calcifying media (ECM) which may be contained between the basal layer of the coral tissue, the calicoblastic epithelia, and the underlying coral skeleton (Allemand et al. 2011) or contained within vesicles in the coral tissue (Mass et al. 2017). This calcification media is semi-isolated from ambient seawater, and both the $\mathrm{pH}$ and dissolved inorganic carbon (DIC) of the media are significantly higher than in local seawater (Sevilgen et al. 2019), facilitating precipitation of the aragonite skeleton. The three predominant forms of dissolved inorganic carbon in seawater are $\mathrm{CO}_{2}$, bicarbonate $\left(\mathrm{HCO}_{3}{ }^{-}\right)$and carbonate $\left(\mathrm{CO}_{3}{ }^{2-}\right)$. Increasing seawater $\mathrm{pH}$ shifts the DIC equilibrium to reduce the proportion of $\mathrm{CO}_{2}$ and increase the proportion of $\mathrm{CO}_{3}{ }^{2-} \cdot \mathrm{CO}_{2}$ can readily diffuse across cell membranes so the $\mathrm{pH}$ increase facilitates the invasion of $\mathrm{CO}_{2}$ into the calcification site and acts as a DIC concentration mechanism (Erez 1978). This allows the [DIC], $\left[\mathrm{HCO}_{3}{ }^{-}\right]$and $\left[\mathrm{CO}_{3}{ }^{2-}\right]$ to increase above that of seawater providing the DIC required to build the skeleton (Allison et al. 2014).

Here, we use skeletal $\delta^{11} \mathrm{~B}$ to estimate the $\mathrm{pH}$ of the calcification media $\left(\mathrm{pH}_{\mathrm{ECM}}\right)$ in a series of corals cultured over a range of seawater $\mathrm{pCO}_{2}(180,260,400$ and 750 $\mu \mathrm{atm}$ ) and at 25 and $28{ }^{\circ} \mathrm{C}$ (Cole et al. 2018). These $\mathrm{pCO}_{2}$ conditions reflect conditions in the Last Glacial Maximum, the pre-industrial (Gattuso and Lavigne 2009), the present day and a future scenario. B speciation in seawater is controlled by ambient $\mathrm{pH}$, and there is a large $\mathrm{B}$ isotope fractionation between the predominate dissolved species with borate, $\mathrm{B}(\mathrm{OH})_{4}{ }^{-}$, depleted in ${ }^{11} \mathrm{~B}$ compared to boric acid, $\mathrm{B}(\mathrm{OH})_{3}$ (Kakihana et al. 1977). Assuming that $\mathrm{B}(\mathrm{OH})_{4}{ }^{-}$is predominantly incorporated into the lattice during aragonite precipitation (Sen et al. 1994; Noireaux et al. 2015; Balan et al. 2016), skeletal $\delta^{11} \mathrm{~B}$ reflects $\mathrm{pH}_{\mathrm{ECM}}$. Reports of $\mathrm{B}(\mathrm{OH})_{3}$ in tropical (Klochko et al. 2009) and deep water corals (Rollion-Bard et al. 2011) may reflect a change in B coordination (from tetrahedral B4 to trigonal B3) after aragonite precipitation (Klochko et al. 2009; Noireaux et al. 2015; Balan et al. 2016) or the incorporation of B3 in coral centres of calcification (Rollion-Bard et al. 2011). In this study, we avoid the analysis of centres of calcification and we assume that coral skeletal boron is derived from dissolved $\mathrm{B}(\mathrm{OH})_{4}{ }^{-}$. It is unclear how avoiding these areas affects our estimates of skeletal $\delta^{11} \mathrm{~B}$. Centres of calcification exhibit different crystal morphologies (Cohen et al. 2001), contain higher concentrations of organic materials (Cuif et al. 2003) and exhibit different geochemistry (Allison 1996) compared to the remainder of the skeleton. However, centres of calcification occupy a small volume of the total skeleton ( $\sim 4 \%$, Allison et al. 2005), so the effect of exclusion of this material from analysis is likely to be small. We determine how $\mathrm{pH}_{\mathrm{ECM}}$ is affected by seawater $\mathrm{pCO}_{2}$ and temperature in four genotypes of massive Porites spp. and we explore how $\mathrm{pH}_{\mathrm{ECM}}$ relates to published calcification rates for these corals (Cole et al. 2018).

\section{Methods and materials}

\section{Coral culturing}

We cultured multiple genotypes of massive Porites spp. corals over a range of seawater $\mathrm{pCO}_{2}(\sim 180,260,400$ and $750 \mu \mathrm{atm})$ and temperature $\left(25\right.$ and $\left.28{ }^{\circ} \mathrm{C}\right)$. Large heads of massive Porites spp. corals were collected in Fiji and imported into the UK. Heads were identified to species level based on corallite morphology (Veron 1993) and were considered to represent different genotypes when they were collected from spatially separate (non-adjoining) colonies. The physiological responses of small experimental corals are not representative of larger colonies (Edmunds and Burgess 2016), and we sawed imported heads into multiple pieces (each $\sim 12 \mathrm{~cm}$ in diameter) so that at least one large piece of each genotype could be cultured in each seawater $\mathrm{pCO}_{2}$ treatment.

Corals were cultured in seawater bubbled with the target air: $\mathrm{CO}_{2}$ gas mixes in a purpose-built large-volume aquarium system (Cole et al. 2016, 2018). For each $\mathrm{pCO}_{2}$ treatment coral pieces were split randomly between 2 tanks of 211 each, fed with seawater recirculated from a highdensity polyethylene reservoir containing $\sim 9001$ of seawater. Only one reservoir was used for each $\mathrm{pCO}_{2}$ treatment. To test for variations between replicate reservoirs results from this study were compared to data collected from a previous study using the same aquarium system and culturing corals over a range of seawater $\mathrm{pCO}_{2}$ at $25^{\circ} \mathrm{C}$ (Allison et al. 2018).

After import, corals were maintained at ambient seawater $\mathrm{pCO}_{2}$ conditions for 2 months, kept under varying $\mathrm{CO}_{2}$ for 1 month, while the seawater $\mathrm{pCO}_{2}$ was gradually adjusted to the treatment conditions and then acclimated at the final treatment $\mathrm{pCO}_{2}$ for 4 months at $28{ }^{\circ} \mathrm{C}$. Colonies were then stained with Alizarin Red S and cultured for a 5-week experimental period during which calcification, respiration and net and gross photosynthesis were measured on 3 or 4 occasions (Cole et al. 2018). At the end of this time, a small segment of each colony (including tissue and skeleton) was removed by rock saw and preserved for future analysis. This reduced the surface areas of each colony by $\sim 25 \%$. Seawater temperatures were then reduced to $25{ }^{\circ} \mathrm{C}$ over a period of 4 weeks and then 
acclimated at this temperature for another month during which time the sawn edges of the coral colonies were overgrown by coral tissue. Finally, corals were restained with Alizarin Red $\mathrm{S}$, physiological rates were measured over a 5-week period as before, and the corals were then sacrificed. Further details on the coral culturing methods are provided in the supplementary information. It is likely that the import procedures and sawing of colonies resulted in some stress to the corals at the start of this study, but it is unlikely that this impacts the data presented here. Corals were cultured for a total of 11 months during this experiment, displayed no evidence of bleaching and maintained photosynthesis, respiration and calcification rates comparable to those of massive Porites spp. in the field (see supplementary information).

\section{Seawater characterisation}

The physical characteristics of the culture seawater are detailed in Cole et al. (2018) and are summarised in Table 1. Dissolved nutrients were measured in filtered samples from each reservoir using a flow cell spectrophotometer (Lachat 8000) at the Scottish Association of Marine Science, the UK. $\left[\mathrm{NO}_{3}{ }^{-}+\mathrm{NO}_{2}{ }^{-}\right]$and $\left[\mathrm{PO}_{4}{ }^{-}\right]$fell to low levels (0.04 and $0.00 \mu \mathrm{M}$, respectively) in the first week of the 5-week experimental period in the $400 \mu \mathrm{atm}$ $\mathrm{pCO}_{2}$ treatment at $28{ }^{\circ} \mathrm{C}$ (Table 1) and the polyps of these corals appeared retracted. After this experimental period, the seawater in this reservoir was discarded and replaced with seawater sourced from the remaining three reservoirs which was bubbled to bring it to seawater $\mathrm{pCO}_{2}$ of 400 $\mu$ atm before use. The geochemistry of these specimens was only analysed in the skeleton deposited at $25^{\circ} \mathrm{C}$. Dissolved nutrients in the remaining treatments did not vary significantly between treatments and were comparable to natural reefs (Szmant 2002).

Seawater samples were collected 2-4 times during each experimental period and analysed by quadrupole ICP-MS (Thermo Scientific X Series) for $\mathrm{Mg}$ and $\mathrm{Ca}$. Samples were diluted 1000 -fold in $5 \% \mathrm{HNO}_{3}$ (with 5 ppb In as an internal standard) and calibrated against matrix-matched synthetic standards prepared from $1000 \mu \mathrm{g} \mathrm{ml}^{-1}$ single-element stock solutions (Inorganic Ventures) in $5 \% \mathrm{HNO}_{3}$. Replicate analyses of IAPSO standard seawater yielded $\mathrm{Mg}$ and Ca precision $(1 \sigma)$ of $1.4 \%$ and $0.6 \%$, respectively.

Seawaters were sampled for $\delta^{11} \mathrm{~B}$ in the first and last weeks of each 5-week experimental period (with the exception of the 400 and $750 \mu$ atm treatments at $25^{\circ} \mathrm{C}$ which were sampled in the first week only). Boron was separated from the seawater matrix by column chromatography (using the boron-specific anionic exchange resin Amberlite IRA 743) and analysed on a Neptune Plus MC-ICPMS (Foster 2008; Rae et al. 2011; Foster et al.
2013). Long-term reproducibility for samples is conservatively estimated at 0.23 permil (2SD). Triplicate analyses of an in-house seawater standard prepared alongside these samples gave a mean value of $39.50 \pm 0.09 \%$ o $(2 \sigma)$.

\section{Estimation of $\mathrm{pH}_{\mathbf{E C M}}$}

After sacrifice, the coral heads were submerged in 3-4\% sodium hypochlorite for $\geq 24 \mathrm{~h}$ with intermittent agitation to remove organic contamination, rinsed repeatedly in distilled water and dried. Colonies were sawn perpendicular to the growth surface to produce strips along the maximum growth axes and fixed in $25 \mathrm{~mm}$ epoxy resin blocks (Epofix, Struers Ltd.). Blocks were polished using silicon carbide papers (up to 4000 grade, lubricated with water) and polishing alumina $(0.05 \mu \mathrm{m}$, suspended in water).

The skeletal $\delta^{11} \mathrm{~B}$ of each experimental period was determined by SIMS using a Cameca 1270 in the School of GeoSciences at the University of Edinburgh. Sections were gold coated and analysed with a primary ${ }^{16} \mathrm{O}^{-}$beam of $\sim 7 \mathrm{nA}$, accelerated at $22 \mathrm{keV}$ and focussed to an oval $\sim 25 \times 35 \mu \mathrm{m}$. Multiple SIMS analyses were evenly spaced across the skeleton deposited in 2-5 different corallites of each colony over each experimental period. Instrument conditions were energy offset $=0 \mathrm{eV}(100 \mathrm{eV}$ window), imaged field $=25 \mu \mathrm{m}$, entrance slits $150 \mu \mathrm{m}$ and exit slits $500 \mu \mathrm{m}$ (mass resolution was $\sim 2400$ ). Secondary ions were collected by a single electron multiplier cycling the magnetic field through the mass range. Singly charged cations were collected at masses ${ }^{10} \mathrm{~B}(11 \mathrm{~s}$ per cycle) and ${ }^{11} \mathrm{~B}(3 \mathrm{~s})$ yielding typical count rates of $\sim 1300$ and $5000 \mathrm{cps}$, respectively. Each analysis is the sum of 60 cycles. A pre-analysis sputter time of $30 \mathrm{~s}$ in spot mode was used to remove surface contamination. Internal reproducibility (the precision at a single point) was calculated from the standard deviation $(\sigma)$ of the 60 cycles in each coral analysis $(\sigma /(\sqrt{ } 60))$ and was typically $1.6 \%$. The precision $(1 \sigma)$ of multiple analyses $(n=9-25)$ of each coral sample was typically $1.5 \%\left(\delta^{11} \mathrm{~B}\right)$.

All analyses were normalized to a Porites spp. coral standard $\quad\left(\delta^{11} \mathrm{~B}=24.8 \%, \quad \mathrm{~B} / \mathrm{Ca}=0.364 \mathrm{mmol} \mathrm{mol}^{-1}\right.$, (Kasemann et al. 2009)). Minor differences in the $\delta^{11} \mathrm{~B}$ of the SIMS coral standard and the chips of the same coral characterised by bulk methods may affect the accuracy but not the precision of SIMS estimates. A Desmophyllum spp. cold water coral chip $\left(\delta^{11} \mathrm{~B} \approx 16.7 \pm 1.2 \%\right.$ o $(1 \sigma) ; \mathrm{B} / \mathrm{Ca} \approx$ $0.15 \mathrm{mmol} \mathrm{mol}^{-1} \pm 3 \%(1 \sigma)$, based on comparison with the coral standard) which exhibited limited heterogeneity in $\delta^{11} \mathrm{~B}$ was analysed to confirm that there was no instrumental drift within and between days. Multiple analyses were completed each day $(n=9-23)$ to yield a $95 \%$ 
Table 1 Physical and chemical characteristics of the seawater and coral skeletons in each treatment, measured over the 5-week experimental period

\begin{tabular}{|c|c|c|c|c|}
\hline & \multicolumn{4}{|l|}{ Seawater $\mathrm{pCO}_{2}$} \\
\hline & $180 \mu \mathrm{atm}$ & $260 \mu \mathrm{atm}$ & $400 \mu \mathrm{atm}$ & $750 \mu \mathrm{atm}$ \\
\hline \multicolumn{5}{|l|}{$25^{\circ} \mathrm{C}$ experiment } \\
\hline Temperature $\left({ }^{\circ} \mathrm{C}\right)$ & $25.0 \pm 0.10$ & $25.0 \pm 0.16$ & $25.2 \pm 0.25$ & $25.0 \pm 0.21$ \\
\hline Salinity & $35.1 \pm 0.1$ & $35.2 \pm 0.0$ & $35.1 \pm 0.1$ & $35.1 \pm 0.0$ \\
\hline Estimated seawater $\mathrm{pH}$ & 8.324 & 8.199 & 8.043 & 7.813 \\
\hline Seawater $\left[\mathrm{Ca}^{2+}\right] \mathrm{mmol} \mathrm{kg}^{-1}$ & $10.3 \pm 0.1$ & $10.6 \pm 0.1$ & $10.4 \pm 0.5$ & $10.7 \pm 0.1$ \\
\hline Seawater $\left[\mathrm{Mg}^{2+}\right] \mathrm{mmol} \mathrm{kg}{ }^{-1}$ & $58.9 \pm 0.2$ & $59.6 \pm 0.4$ & $59.4 \pm 0.6$ & $59.7 \pm 0.5$ \\
\hline Total alkalinity $\mu \mathrm{mol} \mathrm{kg}{ }^{-1}$ & $2194 \pm 48$ & $2228 \pm 45$ & $2255 \pm 15$ & $2235 \pm 29$ \\
\hline Seawater $[\mathrm{DIC}] \mu \mathrm{mol} \mathrm{kg}{ }^{-1}$ & $1862 \pm 7$ & $1947 \pm 17$ & $2025 \pm 30$ & $2129 \pm 20$ \\
\hline Estimated $\Omega_{\text {aragonite }}$ & 5.49 & 4.51 & 3.44 & 2.21 \\
\hline Seawater $[B]\left(\mu \mathrm{mol} \mathrm{kg}^{-1}\right)$ & $259 \pm 1$ & $264 \pm 0$ & $262 \pm 0$ & $264 \pm 1$ \\
\hline Seawater $\delta^{11} \mathrm{~B}(\%)$ & $2.40 \pm 0.00$ & $3.10 \pm 0.05$ & 2.87 & 2.98 \\
\hline \multicolumn{5}{|l|}{ Seawater nutrients } \\
\hline $\mathrm{NH}_{4}^{+} \mu \mathrm{M}$ & $0.54 \pm 0.00$ & $0.57 \pm 0.05$ & $0.12 \pm 0.18$ & $0.44 \pm 0.22$ \\
\hline $\mathrm{PO}_{4}{ }^{3-} \mu \mathrm{M}$ & $0.05 \pm 0.04$ & $0.02 \pm 0.03$ & $0.05 \pm 0.02$ & $0.02 \pm 0.02$ \\
\hline $\mathrm{Si}(\mathrm{OH})_{4} \mu \mathrm{M}$ & $2.74 \pm 1.65$ & $0.97 \pm 0.31$ & $2.44 \pm 0.25$ & $1.15 \pm 0.46$ \\
\hline $\mathrm{NO}_{3}{ }^{-}+\mathrm{NO}_{2}{ }^{-} \mu \mathrm{M}$ & $2.59 \pm 0.06$ & $1.54 \pm 0.31$ & $2.32 \pm 0.34$ & $1.38 \pm 0.09$ \\
\hline \multicolumn{5}{|l|}{ Skeleton $\delta^{11} B(\%)$} \\
\hline Genotype 4 & $-11.03 \pm 0.56$ & $-12.06 \pm 0.73$ & $-12.65 \pm 0.69$ & $-10.79 \pm 0.95$ \\
\hline Genotype 5 & $-9.49 \pm 1.21$ & $-10.75 \pm 0.88$ & $-12.19 \pm 0.64$ & $-14.42 \pm 0.64$ \\
\hline Genotype 6 & $-9.14 \pm 0.55$ & $-9.80 \pm 0.66$ & $-11.96 \pm 0.97$ & $-14.53 \pm 1.15$ \\
\hline Genotype 7 & $-11.25 \pm 0.76$ & $-11.0 \pm 0.78$ & $-11.68 \pm 0.59$ & $-12.79 \pm 0.59$ \\
\hline \multicolumn{5}{|l|}{$p H_{E C M}($ total scale $)$} \\
\hline Genotype 4 & $8.58 \pm 0.08$ & $8.46 \pm 0.08$ & $8.43 \pm 0.10$ & $8.55 \pm 0.14$ \\
\hline Genotype 5 & $8.69 \pm 0.19$ & $8.55 \pm 0.13$ & $8.47 \pm 0.11$ & $8.30 \pm 0.08$ \\
\hline Genotype 6 & $8.71 \pm 0.09$ & $8.61 \pm 0.09$ & $8.48 \pm 0.14$ & $8.28 \pm 0.19$ \\
\hline Genotype 7 & $8.56 \pm 0.12$ & $8.53 \pm 0.11$ & $8.49 \pm 0.09$ & $8.42 \pm 0.09$ \\
\hline \multicolumn{5}{|l|}{$28^{\circ} \mathrm{C}$ experiment } \\
\hline Temperature $\left({ }^{\circ} \mathrm{C}\right)$ & $28.0 \pm 0.09$ & $28.0 \pm 0.18$ & $28.0 \pm 0.22$ & $28.0 \pm 0.09$ \\
\hline Salinity & $35.1 \pm 0.05$ & $35.1 \pm 0.07$ & $35.1 \pm 0.09$ & $35.1 \pm 0.09$ \\
\hline Estimated seawater $\mathrm{pH}$ & 8.302 & 8.194 & 8.043 & 7.814 \\
\hline Seawater $\left[\mathrm{Ca}^{2+}\right] \mathrm{mmol} \mathrm{kg}^{-1}$ & $10.1 \pm 0.1$ & $10.7 \pm 0.0$ & 10.9 & $10.7 \pm 0.0$ \\
\hline Seawater $\left[\mathrm{Mg}^{2+}\right] \mathrm{mmol} \mathrm{kg}{ }^{-1}$ & $58.5 \pm 0.3$ & $59.0 \pm 0.3$ & 58.3 & $59.3 \pm 0.2$ \\
\hline Total alkalinity $\mu \mathrm{mol} \mathrm{kg}{ }^{-1}$ & $2189 \pm 38$ & $2282 \pm 18$ & $2281 \pm 16$ & $2281 \pm 17$ \\
\hline Seawater $[\mathrm{DIC}] \mu \mathrm{mol} \mathrm{kg}{ }^{-1}$ & $1757 \pm 39$ & $1910 \pm 11$ & $1999 \pm 14$ & $2113 \pm 23$ \\
\hline Estimated $\Omega_{\text {aragonite }}$ & 5.50 & 4.86 & 3.76 & 2.46 \\
\hline Seawater $[B]\left(\mu \mathrm{mol} \mathrm{kg}^{-1}\right)$ & $264 \pm 1$ & $268 \pm 0$ & 270 & $267 \pm 2$ \\
\hline Seawater $\delta^{11} \mathrm{~B}(\% \mathrm{o})$ & $4.08 \pm 0.10$ & $4.27 \pm 0.11$ & $4.86 \pm 0.09$ & $3.86 \pm 0.05$ \\
\hline \multicolumn{5}{|l|}{ Seawater nutrients } \\
\hline $\mathrm{NH}_{4}^{+} \mu \mathrm{M}$ & $0.14 \pm 0.03$ & $0.08 \pm 0.02$ & $0.07 \pm 0.07$ & $0.11 \pm 0.09$ \\
\hline $\mathrm{PO}_{4}{ }^{3-} \mu \mathrm{M}$ & $0.01 \pm 0.02$ & $0.01 \pm 0.02$ & $0.00 \pm 0.03$ & $0.02 \pm 0.03$ \\
\hline $\mathrm{Si}(\mathrm{OH})_{4} \mu \mathrm{M}$ & $2.59 \pm 1.39$ & $2.48 \pm 2.64$ & $1.60 \pm 0.81$ & $0.91 \pm 0.66$ \\
\hline $\mathrm{NO}_{3}{ }^{-}+\mathrm{NO}_{2}{ }^{-} \mu \mathrm{M}$ & $2.05 \pm 2.69$ & $0.72 \pm 0.92$ & $0.44 \pm 0.65$ & $0.83 \pm 1.06$ \\
\hline \multicolumn{5}{|l|}{ Skeleton $\delta^{11} B(\%)$} \\
\hline Genotype 4 & $-10.32 \pm 1.2$ & na & na & $-9.23 \pm 0.89$ \\
\hline Genotype 5 & $-8.70 \pm 1.41$ & $-9.98 \pm 0.73$ & na & $-12.86 \pm 0.72$ \\
\hline Genotype 6 & $-8.28 \pm 1.11$ & $-7.28 \pm 0.70$ & na & $-13.10 \pm 0.95$ \\
\hline
\end{tabular}


Table 1 continued

\begin{tabular}{lllll}
\hline & \multicolumn{2}{l}{ Seawater $\mathrm{pCO}_{2}$} & & \\
\cline { 2 - 4 } & $180 \mu \mathrm{atm}$ & $260 \mu \mathrm{atm}$ & natm & \\
\hline Genotype 7 & $-10.80 \pm 0.78$ & $-10.34 \pm 0.70$ & & \\
$p H_{E C M}$ (total scale) & & & na & $8.65 \pm 0.55$ \\
Genotype 4 & $8.48 \pm 0.12$ & na & na & $8.37 \pm 0.12$ \\
Genotype 5 & $8.59 \pm 0.21$ & $8.49 \pm 0.12$ & na & $8.29 \pm 0.17$ \\
Genotype 6 & $8.62 \pm 0.17$ & $8.67 \pm 0.11$ & na & $8.33 \pm 0.09$ \\
Genotype 7 & $8.45 \pm 0.11$ & $8.46 \pm 0.11$ & \\
\hline
\end{tabular}

Seawater values are mean \pm standard deviation $(1 \sigma)$. Seawater $\mathrm{pH}$ (total scale) is estimated from measured dissolved inorganic carbon (DIC) and $\mathrm{pCO}_{2}$ measurements (Cole et al. 2018) using $\mathrm{CO}_{2}$ sys MATLAB (version 1.1,(van Heuven, 2011), equilibrium constants for carbonic acid from (Mehrbach et al. 1973), refit by (Dickson and Millero 1987) and for $\mathrm{KHSO}_{4}$ from (Dickson 1990)

confidence limit of the mean $\delta^{11} \mathrm{~B}$ of the standard which was typically $\sim 1.0 \%$ and was always better than $\pm 1.4 \%$.

$\mathrm{pH}_{\mathrm{ECM}}$ was estimated from skeletal $\delta^{11} \mathrm{~B}$ as:

$\mathrm{pH}_{\mathrm{ECM}}=p K_{\mathrm{B}}-\log \left(-\delta^{11} \mathrm{~B}_{\mathrm{ECM}}-\delta^{11} \mathrm{~B}_{\text {skeleton }}\right)$

$\delta^{11} \mathrm{~B}_{\mathrm{ECM}}-\alpha_{\mathrm{B}} \delta^{11} \mathrm{~B}_{\text {skeleton }}-1000\left(\alpha_{\mathrm{B}}-1\right)$

using $\alpha_{\mathrm{B}}(=1.0266$, the mean of two empirical estimates Klochko et al. 2006; Nir et al. 2015), $p K_{\mathrm{B}}$ calculated from measured temperatures and salinity and assuming that the $\delta^{11} \mathrm{~B}$ of the calcification fluid $\left(\delta^{11} \mathrm{~B}_{\mathrm{ECM}}\right)$ is the same as culture seawater (Table 1).

\section{Results}

The culture system parameters, seawater and skeletal $\delta^{11} \mathrm{~B}$ data and calculated $\mathrm{pH}_{\mathrm{ECM}}$ are summarised in Table 1. We adopt the same genotype numbering convention used in Cole et al.2018 to facilitate comparison with the calcification data published previously. We report all $\mathrm{pH}$ on the total scale and use the subscripts ${ }_{\mathrm{ECM}}$ and $\mathrm{Sw}$ to denote the extracellular calcifying media and seawater, respectively. Both the $[\mathrm{B}]$ and $\delta^{11} \mathrm{~B}$ of the artificial seawater (Table 1) were different from that of natural seawater $\left([B]=416-432 \mu \mathrm{mol} \mathrm{kg}^{-1}\right.$ (Uppstrom 1974; Lee et al. 2010), $\delta^{11} \mathrm{~B}=39.61 \%$ (Foster et al. 2010). B evaporates in the water phase during seawater evaporation (Gast and Thompson 1959) to form aquarium seasalt and is replaced by the addition of boric acid by the manufacturer. Other seawater parameters (total alkalinity, $\left[\mathrm{Ca}^{2+}\right],\left[\mathrm{Mg}^{2+}\right]$ ) were comparable to natural seawater (Table 1).

All corals increased the $\mathrm{pH}_{\mathrm{ECM}}$ above that of seawater at both temperatures (Table 1, Fig. 1). Significant variations in $\mathrm{pH}_{\mathrm{ECM}}$ occur both between the same coral genotype in different seawater $\mathrm{pCO}_{2}$ treatments and between different coral genotypes within the same seawater $\mathrm{pCO}_{2}$ treatment

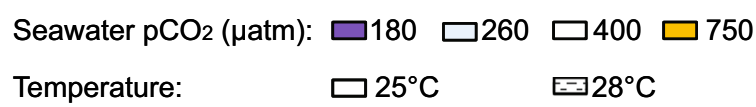

a
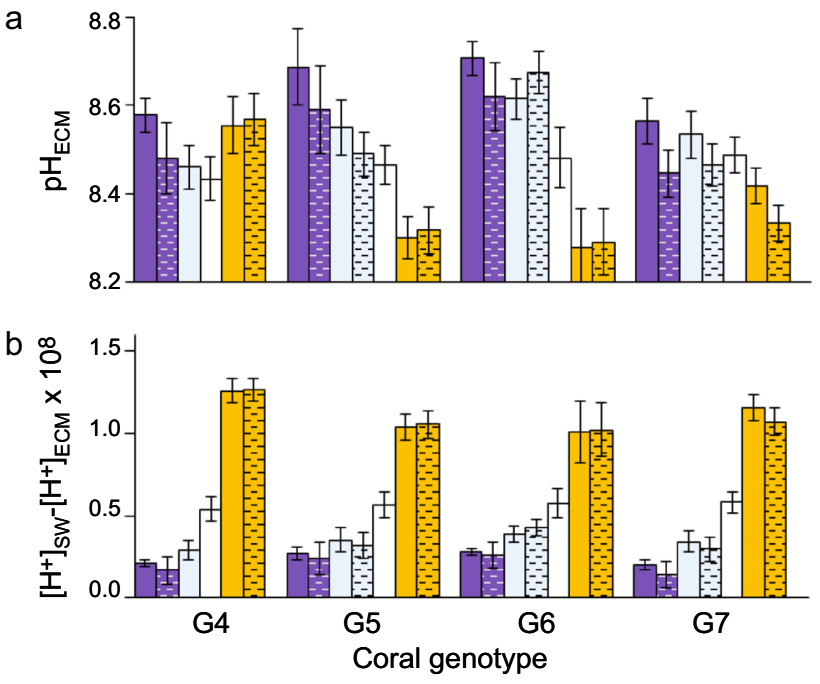

Fig. 1 a $\mathrm{pH}_{\mathrm{ECM}}(\mathrm{pH}$ extracellular calcification media, total scale) and b the $\left[\mathrm{H}^{+}\right]$concentration gradient between seawater and the ECM in all corals. Error bars are calculated from $95 \%$ confidence limits of skeletal $\delta^{11} \mathrm{~B}$ analyses at 25 and $28{ }^{\circ} \mathrm{C}$. Genotype numbering (G4-G7) follows that used in Cole et al. (2018). Hatched bars indicate results at $28^{\circ} \mathrm{C}$, and unhatched bars are $25^{\circ} \mathrm{C}$

(one-way ANOVA, Table 2). $\mathrm{pH}_{\mathrm{ECM}}$ is significantly higher in all coral genotypes at seawater $\mathrm{pCO}_{2} 180 \mu \mathrm{atm}$ compared to $750 \mu \mathrm{atm}$ at both 25 and $28{ }^{\circ} \mathrm{C}$ (with the exception of $\mathrm{G} 4$ at $25^{\circ} \mathrm{C}$, Table 2). Mean $\mathrm{pH}_{\mathrm{ECM}}$ is significantly lower at $28{ }^{\circ} \mathrm{C}$ compared to $25{ }^{\circ} \mathrm{C}$ in corals cultured at 180 $\mu$ atm (paired 2 tailed $\mathrm{t}$ test of all 4 coral genotypes, $p=0.00053$ ) but not in the same coral genotypes cultured at the two temperatures at $750 \mu \mathrm{atm}(p=0.65)$. Minor changes in pHsw occur between 25 and $28{ }^{\circ} \mathrm{C}$ within some $\mathrm{pCO}_{2}$ treatments (Table 1). To account for this, we also tested if the proton concentration gradient between the 
Table 2 Summary of significant differences $(p \leq 0.05$, one-way ANOVA followed by Tukey's pairwise comparisons) in calcification fluid $\mathrm{pH}$ between individuals of the same coral genotype in different seawater $\mathrm{pCO}_{2}$ treatments and between individuals of different genotypes within the same seawater $\mathrm{pCO}_{2}$ treatment
Genotype/ $\mathrm{pCO}_{2}$ treatment $\quad$ Significant differences $(p \leq 0.05)$

Differences in calcification fluid $\mathrm{pH}$ between $\mathrm{pCO}_{2}$ treatments at $25^{\circ} \mathrm{C}$ within each coral genotype

Genotype $4 \quad 180>260,400 ; 750>400$

Genotype $5 \quad 180>260,400,750 ; 260>750 ; 400>750$

Genotype $6 \quad 180>400,750 ; 260>400,750 ; 400>750$

Genotype $7 \quad 180>400,750$

Differences in calcification fluid $\mathrm{pH}$ between $\mathrm{pCO}_{2}$ treatments at $28{ }^{\circ} \mathrm{C}$ within each coral genotype

Genotype 4 no significant differences

Genotype $5 \quad 180>750 ; 260>750$

Genotype $6 \quad 180>750 ; 260>750$

Genotype $7 \quad 180>750 ; 260>750$

Differences in calcification fluid $\mathrm{pH}$ between coral genotypes at $25{ }^{\circ} \mathrm{C}$ within each $\mathrm{pCO}_{2}$ treatment

$180 \mu \mathrm{atm} \quad \mathrm{G} 6>\mathrm{G} 1 ; \mathrm{G} 6>\mathrm{G} 7, \mathrm{G} 5>\mathrm{G} 7$

$260 \mu \mathrm{atm} \quad \mathrm{G} 6>\mathrm{G} 4$

$400 \mu \mathrm{atm} \quad$ no significant differences

$750 \mu \mathrm{atm} \quad \mathrm{G} 4>\mathrm{G} 5, \mathrm{G} 6, \mathrm{G} 7 ;$ G7 > G6

Differences in calcification fluid $\mathrm{pH}$ between coral genotypes at $28{ }^{\circ} \mathrm{C}$ within each $\mathrm{pCO}_{2}$ treatment

$\begin{array}{ll}180 \mu \mathrm{atm} & \mathrm{G} 6>\mathrm{G} 7 \\ 260 \mu \mathrm{atm} & \mathrm{G} 6>\mathrm{G} 5, \mathrm{G} 7 \\ 750 \mu \mathrm{atm} & \mathrm{G} 4>\mathrm{G} 5, \mathrm{G} 6, \mathrm{G} 7\end{array}$

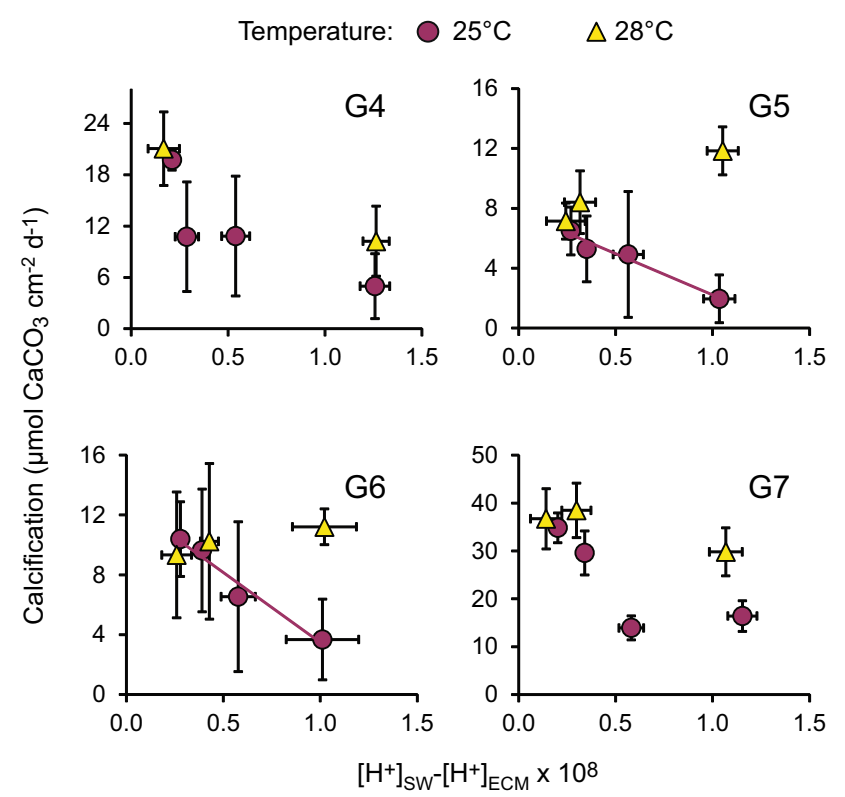

Fig. 2 Calcification rates as a function of the $\left[\mathrm{H}^{+}\right]_{\mathrm{sw}}-\left[\mathrm{H}^{+}\right]_{\mathrm{ECM}}$ gradient at $25{ }^{\circ} \mathrm{C}$ and $28{ }^{\circ} \mathrm{C}$. The two significant correlations $(p \leq 0.05)$ are indicated by solid lines. Error bars indicate $95 \%$ confidence limits in $\mathrm{pH}_{\mathrm{ECM}}$ and $1 \sigma$ of calcification measurements. Genotype numbering (G4-G7) follows that used in Cole et al. (2018)

seawater and the ECM (i.e. $\left[\mathrm{H}^{+}\right]_{\mathrm{sw}}-\left[\mathrm{H}^{+}\right]_{\mathrm{ECM}}$ ) varied between corals. Mean $\left[\mathrm{H}^{+}\right]_{\mathrm{sw}}-\left[\mathrm{H}^{+}\right]_{\mathrm{ECM}}$ of all four coral genotypes is significantly lower at $28{ }^{\circ} \mathrm{C}$ compared to $25{ }^{\circ} \mathrm{C}$ in corals cultured at $180 \mu$ atm (paired 2 tailed t test,
Table 3 Coefficients of determination $\left(\mathrm{r}^{2}\right)$ between $[\mathrm{H}+]_{\mathrm{sw}^{-}}$ $[\mathrm{H}+]_{\mathrm{ECM}}$ and coral calcification rates at each temperature for each coral genotype.

\begin{tabular}{lll}
\hline Coral genotype & $25{ }^{\circ} \mathrm{C}$ & $28^{\circ} \mathrm{C}$ \\
\hline G4 & $0.69(p=0.169)$ & na \\
G5 & $0.96(p=0.018)$ & $0.82(p=0.113)$ \\
G6 & $0.96(p=0.021)$ & $0.91(p=0.190)$ \\
G7 & $0.59(p=0.230)$ & $0.88(p=0.222)$ \\
\hline
\end{tabular}

$p$ values are shown in parentheses. na $=$ not analysed

$p=0.028)$ but again differences are not significant in the same coral genotypes cultured at $750 \mu$ atm $(p=0.63)$.

We plot coral calcification rate as a function of the $\left[\mathrm{H}^{+}\right]_{\mathrm{sw}}-\left[\mathrm{H}^{+}\right]_{\mathrm{ECM}}$ gradient between the calcifying media and the surrounding seawater (Fig. 2). Calcification rate and the $\left[\mathrm{H}^{+}\right]$gradient are significantly correlated at $25{ }^{\circ} \mathrm{C}$ in genotypes $\mathrm{G} 3$ and $\mathrm{G} 6$, but all other relationships are not significant (Table 3). This partly reflects the small numbers in the regression analysis ( $=3$ or 4$)$, but it is noteworthy that calcification rate and the $\left[\mathrm{H}^{+}\right]$gradient are inversely related in all corals at $25{ }^{\circ} \mathrm{C}$ but demonstrate much more mixed behaviour at $28{ }^{\circ} \mathrm{C}$.

Only one reservoir was used for each $\mathrm{pCO}_{2}$ treatment, and to estimate variations between replicate reservoirs, we compare the results from this study to those of a previous study using the same aquarium system and culturing corals 
at 180,400 and $750 \mu$ atm seawater $\mathrm{pCO}_{2}$ at $25{ }^{\circ} \mathrm{C}$ (Allison et al. 2018). We observe no significant difference in the $\mathrm{pH}_{\mathrm{ECM}}$ between groups of corals cultured under the same conditions in both studies ( $\mathrm{t}$ test, $p>0.05$ ) indicating that variations between replicate reservoirs are insignificant.

\section{Discussion}

Increasing seawater temperature from 25 to $28{ }^{\circ} \mathrm{C}$ significantly reduced $\mathrm{pH}_{\mathrm{ECM}}$ (and the $\mathrm{H}^{+}$gradient between the calcification media and the ambient seawater) at $180 \mu \mathrm{atm}$ but had no significant effect at $750 \mu \mathrm{atm}$. Coral calcification rates did not change significantly between 25 and $28{ }^{\circ} \mathrm{C}$ in the $180 \mu$ atm treatment but increased significantly at high seawater $\mathrm{pCO}_{2}$ (Cole et al. 2018). Previous studies linking temperature and $\mathrm{pH}_{\mathrm{ECM}}$ generate mixed reports. Temperature had little effect on $\mathrm{pH}_{\mathrm{ECM}}$ of Acropora spp. cultured at ambient and high $\mathrm{pCO}_{2}$ (Reynaud et al. 2004; Dissard et al. 2012). $\mathrm{pH}_{\mathrm{ECM}}$ showed little change in massive Porites spp cultured in an outdoor flume system in response to a $3{ }^{\circ} \mathrm{C}$ seasonal seawater temperature change at ambient $\mathrm{pCO}_{2}$ and a small reduction (in $\mathrm{pH}_{\mathrm{ECM}}$ ) during the cooler months at high $\mathrm{pCO}_{2}$ (Comeau et al. 2019). In contrast, a broad inverse correlation was reported between temperature and $\mathrm{pH}_{\mathrm{ECM}}$ in modern field corals (i.e. growing at atmospheric $\mathrm{pCO}_{2}$ ) from varying localities in Western Australia (Ross et al. 2019). These discrepancies could reflect the role of other influences on $\mathrm{pH}_{\mathrm{ECM}}$. Increasing seawater $\mathrm{pCO}_{2}$ reduced $\mathrm{pH}_{\mathrm{ECM}}$ more in the dark than the light in some coral species (Venn et al. 2019) and seasonal variations in light availability in the flume experiments may affect $\mathrm{pH}_{\mathrm{ECM}}$ estimates which combine skeleton deposited during both the day and night (Comeau et al. 2019). The corals in this study were maintained at a constant light regime throughout the study, so this factor is not responsible for changes in $\mathrm{pH}_{\mathrm{ECM}}$ here.

Aragonite precipitation rates are influenced by fluid saturation state (a measure of the relative concentrations of the ions utilised in precipitation), temperature and the presence of biomolecules (Burton and Walter 1987; Kellock et al. 2020). We consider the influences of these factors in the two sections below.

\section{The effects of $\Omega$ and temperature on aragonite precipitation}

The aragonite saturation state $(\Omega)$ is defined as a function of the $\left[\mathrm{Ca}^{2+}\right]$ and $\left[\mathrm{CO}_{3}{ }^{2-}\right]$ of seawater although $\mathrm{HCO}_{3}{ }^{-}$ may also be involved in $\mathrm{CaCO}_{3}$ precipitation (Wolthers et al. 2012). $\left[\mathrm{Ca}^{2+}\right]_{\mathrm{ECM}}$ is similar (Al-Horani et al. 2003) or slightly increased (Sevilgen et al. 2019) above that of ambient seawater so variations in $\mathrm{ECM} \Omega$ are predominantly influenced by both the $\mathrm{pH}$ and the DIC concentration of the media which combine to control $\left[\mathrm{CO}_{3}{ }^{2-}\right]$.

Two methods have been proposed to predict the $\left[\mathrm{CO}_{3}{ }^{2-}\right]$ or $\Omega$. Combined measurements of the $\mathrm{B} / \mathrm{Ca}$ and $\delta^{11} \mathrm{~B}$ of the coral aragonite may yield $\mathrm{ECM}\left[\mathrm{CO}_{3}{ }^{2-}\right]$ assuming that $\mathrm{B}(\mathrm{OH})_{4}{ }^{-}$competes with either $\mathrm{CO}_{3}{ }^{2-}$ or $\mathrm{HCO}_{3}{ }^{-}$for substitution into $\mathrm{CO}_{3}{ }^{2-}$ sites in the aragonite lattice (Allison et al. 2014). Alternatively, the full width half maxima (FWHM) of the $v_{1}$ peak in the aragonite Raman spectrum has been postulated as an indicator of seawater/ECM saturation state (De Carlo et al. 2017). Both of these approaches offer promise but we believe that neither of them has yet been constrained accurately enough to be applied to biogenic carbonates. For both approaches, the relationships between the proxy and the seawater saturation state or $\left[\mathrm{CO}_{3}{ }^{2-}\right]$ have been developed from a series of inorganic aragonite precipitation experiments (Holcomb et al. 2016). The $\mathrm{Ca}^{2+}$ consumed during precipitation of the aragonite in these experiments was not replaced and seawater $\left[\mathrm{Ca}^{2+}\right]$ varied significantly within each precipitation (by $\sim \times 3$ ). This resulted in large changes in fluid saturation state within each precipitation and is likely to have significantly affected both aragonite $\mathrm{B} / \mathrm{Ca}$ (as observed in calcite, Gabitov et al. 2014) and the Raman spectra (De Carlo et al. 2017). This undermines the effective use of these proxies to reconstruct ECM $\left[\mathrm{CO}_{3}{ }^{2-}\right]$ and $\Omega$. We also note that the inclusion of organic molecules in $\mathrm{CaCO}_{3}$ influences the FWHM of the $v_{1}$ peak (Ihli et al. 2019). There are large variations in the biomolecule compositions of coral skeletons (Coronado et al. 2019; Kellock et al. 2020), and this will complicate any interpretation of ECM $\Omega$ from Raman spectra.

To explore the potential relationship between temperature and coral calcification rate, we use synthetic aragonite precipitation rates observed at 5, 25 and $37{ }^{\circ} \mathrm{C}$ (Burton and Walter 1987) to calculate the precipitation rates of inorganic aragonite as a function of temperature and $\Omega$ (Fig. 3a,b). We overlay the observed coral calcification rates (Cole et al. 2018) onto this graph assuming that the corals cultured at $400 \mu \mathrm{atm}$ and $25^{\circ} \mathrm{C}$ have a mean $\Omega_{\mathrm{ECM}}=12$ (equivalent to that calculated from $\mathrm{pH}$ and $\left[\mathrm{CO}_{3}{ }^{2-}\right]$ measured by microsensors in Stylophora pistillata cultured at $400 \mu \mathrm{atm}$ and $25{ }^{\circ} \mathrm{C}$ (Sevilgen et al. 2019) an arbitrary precipitation rate equivalent to that observed at this $\Omega$ and $25^{\circ} \mathrm{C}$ in inorganic aragonites, i.e. $2.1 \mu \mathrm{mol} \mathrm{m}{ }^{-2} \mathrm{~h}^{-1}$ (Burton and Walter 1987). We scale linearly all other coral precipitation rates to this value and overlay them onto the graph to estimate $\Omega_{\mathrm{ECM}}$ (Fig. 3b). The effects of increasing temperature on coral calcification rate are consistent with decreases in $\Omega_{\mathrm{ECM}}$ at low seawater $\mathrm{pCO}_{2}$ and an increase in $\Omega_{\mathrm{ECM}}$ at high seawater $\mathrm{pCO}_{2}$. Although inferred $\Omega_{\mathrm{ECM}}$ may decline at higher 


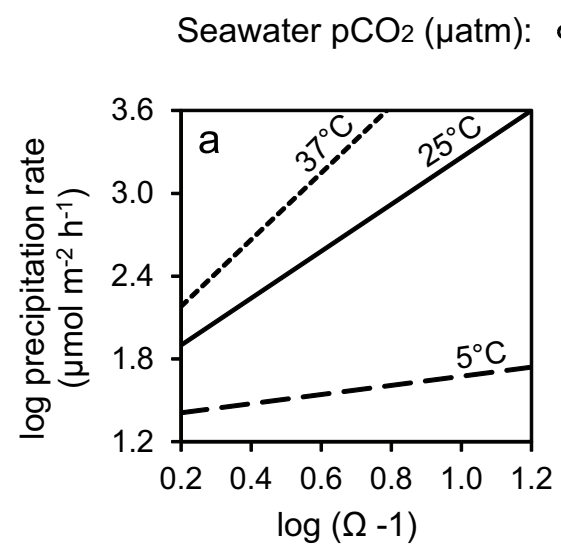

Fig. 3 Temperature effects on precipitation rates in corals and inorganic aragonites. a Inorganic aragonite precipitation rates at three temperatures as a function of $\Omega$ (aragonite saturation state, redrawn from (Burton and Walter 1987)). b Mean coral precipitation (calcification) rates in each seawater $\mathrm{pCO}_{2}$ treatment (Cole et al. 2018) overlaid onto inorganic aragonite precipitation rate contours (in

temperatures in the 180 and $260 \mu \mathrm{atm}$ treatments, the impact of temperature on aragonite precipitation is sufficient to offset this reduction. In contrast, at high seawater $\mathrm{pCO}_{2}$, the inferred $\Omega_{\mathrm{ECM}}$ increases in tandem with temperature enabling the coral to accelerate calcification to a much greater extent than observed at low seawater $\mathrm{pCO}_{2}$. Increasing temperature marginally shifts the DIC equilibrium to favour the speciation of $\mathrm{CO}_{3}{ }^{2-}$ at constant $\mathrm{pH}$ and DIC (Mehrbach et al. 1973) and marginally increases $\Omega$ at constant $\mathrm{pH}$ and $\left[\mathrm{CO}_{3}{ }^{2-}\right]$. However, the relatively large variations in $\Omega_{\mathrm{ECM}}$ suggested by this inorganic aragonite exercise are consistent with a decrease in $[\mathrm{DIC}]_{\mathrm{ECM}}$ at low seawater $\mathrm{pCO}_{2}$ and an increase in $[\mathrm{DIC}]_{\mathrm{ECM}}$ at high seawater $\mathrm{pCO}_{2}$.

\section{The role of the skeletal organic matrix in aragonite precipitation}

In the above exercise, we assume that coral calcification is only influenced by $\Omega_{\mathrm{ECM}}$ and temperature. However, this is an oversimplification. Corals produce a skeletal organic matrix composed of proteins, sugars, polysaccharides and lipids which controls mineral precipitation (Falini et al. 2015). Observations of modern day Porites spp. corals, growing over a range of seawater $\Omega$, indicate that skeletal density is reduced at low seawater $\Omega$ but that linear extension is not affected (Mollica et al. 2018). These variations are not driven by ECM DIC conditions and likely reflect the role of the skeletal organic matrix in skeletogenesis. Aspartic acid, the most common amino acid in the coral skeletal organic matrix (Cuif et al. 1999), inhibits aragonite precipitation at the concentrations inferred to occur at the coral calcification site (Kellock

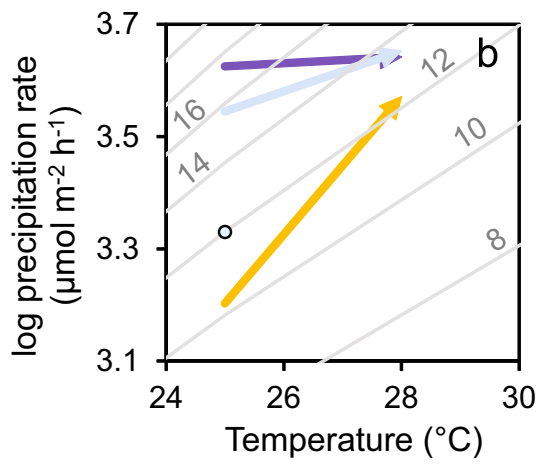

pale grey for different $\Omega$ ) replotted as a function of temperature. We assume that corals cultured at $400 \mu \mathrm{atm}$ and $25{ }^{\circ} \mathrm{C}$ have a $\Omega_{\mathrm{ECM}}=12$ (Sevilgen et al. 2019) and a precipitation rate equivalent to that observed at $\Omega=12$ and $25^{\circ} \mathrm{C}$ in inorganic aragonites (Burton and Walter 1987). We scale linearly all other coral precipitation rates to this value

et al. 2020). The degree of inhibition increases at low seawater $\Omega$ and at higher [aspartic acid]. Skeletal aspartic acid and total amino acid concentrations in cultured Porites spp. corals are positively correlated with seawater $\mathrm{pCO}_{2}$ (Kellock et al. 2020). Reducing $\Omega_{\mathrm{ECM}}$ and increasing skeletal [aspartic acid], as can occur in corals at high $\mathrm{pCO}_{2}$, both act to increase the degree of aspartic acid inhibition of aragonite precipitation and can contribute to reduced coral calcification rates under ocean acidification. We know of no reports that constrain the effect of temperature on the skeletal organic matrix, however, changes in the concentration, composition and behaviour of the skeletal organic matrix will influence coral calcification rate. Increasing temperature had no significant effect on $\mathrm{pH}_{\mathrm{ECM}}$ at high $\mathrm{pCO}_{2}$ but reduced $\mathrm{pH}_{\mathrm{ECM}}$ at low seawater $\mathrm{pCO}_{2}$. If reduced $\mathrm{pH}_{\mathrm{ECM}}$ is associated with reduced $\Omega_{\mathrm{ECM}}$, then this offset between $\mathrm{pCO}_{2}$ treatments may explain why calcification rates remain similar between 25 and $28^{\circ} \mathrm{C}$ at low seawater $\mathrm{pCO}_{2}$ (reduced $\Omega_{\mathrm{ECM}}$ enhances any aspartic acid inhibition of aragonite precipitation) but accelerates at high seawater $\mathrm{pCO}_{2}$ (increased $\Omega_{\mathrm{ECM}}$ decreases any aspartic acid inhibition of aragonite precipitation).

\section{Insights into controls on $\mathbf{p H}_{\mathrm{ECM}}$}

Changes in $\mathrm{pH}_{\mathrm{ECM}}$ between corals and temperatures could reflect changes in calcification (reducing $\mathrm{pH}_{\mathrm{ECM}}$ ), in the influx/efflux of relevant solutes to/from the calcification site or in the activity of carbonic anhydrase (CA) enzymes that catalyse the interconversion of $\mathrm{CO}_{2}+\mathrm{H}_{2} \mathrm{O}$ and $\mathrm{HCO}_{3}{ }^{-}+\mathrm{H}^{+}$. Both calcium adenosine triphosphatase (Ca-ATPase) and a bicarbonate anion transporter (BAT) have been localised to the plasma membrane of the 
calicoblastic cells and remove $\mathrm{H}^{+}$and add $\mathrm{HCO}_{3}{ }^{-}$to the ECM, respectively (Zoccola et al. 2004, 2015), see Fig. 4. The activities of calcification-related enzymes and solute carriers and the expression of the genes which encode them can be affected by both temperature and seawater $\mathrm{pCO}_{2}$ (Edge et al. 2005; Barshis et al. 2013; Kenkel et al. 2013; Maor-Landaw et al. 2014; Zoccola et al. 2016; Kurihara et al. 2018; Yuan et al. 2018). Temperature increases, below the denaturing threshold, usually promote enzyme activity, e.g. increasing temperature enhances the efficiencies of coral Ca-ATPase (Ip et al. 1991) and coral CAs (Zoccola et al. 2016) over the temperature range studied here $\left(25-28^{\circ} \mathrm{C}\right)$. Ca-ATPase uses ATP as an energy source for $\mathrm{Ca}^{2+}$ transport; however, respiration rates did not change significantly between 25 and $28{ }^{\circ} \mathrm{C}$ in the corals cultured at $750 \mu \mathrm{atm} \mathrm{pCO}_{2}$ (Cole et al. 2018) implying that the corals are maintaining a steady energy expenditure (Fig. 4). Ca-ATPase is only one component of the energy budget and temperature-driven increases in the activities of other biological processes (reducing their energy demand) could offset any increase in energy demand by Ca-ATPase. In contrast, respiration rates in corals cultured at $180 \mu \mathrm{atm}$ $\mathrm{pCO}_{2}$ were significantly lower (two-tailed paired test, $p=0.03$ ) at $28{ }^{\circ} \mathrm{C}$ (by $\sim 20 \%$ ) than at $25{ }^{\circ} \mathrm{C}$ (Cole et al. 2018). This implies that coral metabolic costs, including calcification, are reduced at the higher temperature although individuals maintain similar calcification rates at 25 and $28^{\circ} \mathrm{C}$ in spite of this. In this case, the reduction in energy expenditure, e.g. reducing synthesis of calcificationbased enzymes and carriers, could be balanced by temperature enhancement of the activities of the enzyme and solute carriers which are present coupled with the temperature promotion of aragonite precipitation. This hypothesis is consistent with evidence that temperaturedriven increases in enzyme activity may even offset gene downregulation in response to ocean acidification (Zoccola et al. 2016).

Seawater acidification increases the permeability of the coral tissue and could accelerate the paracellular transport of ions $\left(\mathrm{H}^{+}\right.$, DIC species, $\left.\mathrm{Ca}^{2+}\right)$ along concentration gradients to and from the calcification site (Venn et al. 2020). Increasing temperature in that study had no effect on paracellular permeability. The $\left[\mathrm{H}^{+}\right]_{\mathrm{sw}}-\left[\mathrm{H}^{+}\right]_{\mathrm{ECM}}$ gradient in the current study is much higher at low seawater $\mathrm{pCO}_{2}$ (Venn et al. 2013, 2019; Schoepf et al. 2017) regardless of temperature indicating that any increased paracellular permeability is offset by enhanced $\mathrm{H}^{+}$transport out of the ECM. Strong inverse correlations were observed between $\left[\mathrm{H}^{+}\right]_{\mathrm{sw}}-\left[\mathrm{H}^{+}\right]_{\mathrm{ECM}}$ and coral calcification in Porites spp. cultured at $25^{\circ} \mathrm{C}$ (Cole et al. 2018) suggesting that the $\left[\mathrm{H}^{+}\right]_{\mathrm{sw}}-\left[\mathrm{H}^{+}\right]_{\mathrm{ECM}}$ gradient may provide an indication of the energy budget available to meet the demands of calcification, i.e. for solute transport and for the synthesis of the skeletal organic matrix (Allison et al. 2018). In this study, corals exhibit similar inverse correlations at $25^{\circ} \mathrm{C}$ but more mixed relationships at $28{ }^{\circ} \mathrm{C}$ (Fig. 2). The breakdown of these correlations implies that $\left[\mathrm{H}^{+}\right]_{\mathrm{sw}}-\left[\mathrm{H}^{+}\right]_{\mathrm{ECM}}$ alone does not provide a good indication of the potential of the coral to calcify at higher temperatures. Other factors, e.g. the ability of the coral to synthesise the organic matrix used to mediate aragonite precipitation, may also be important. We observe no significant relationships between net

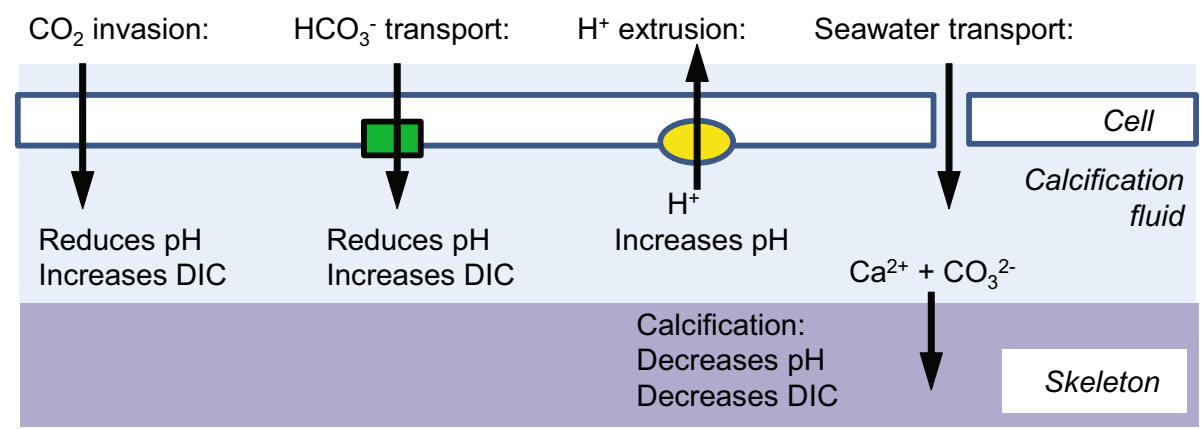

Effects of temperature increase from $25^{\circ} \mathrm{C}$ to $28^{\circ} \mathrm{C}$ :

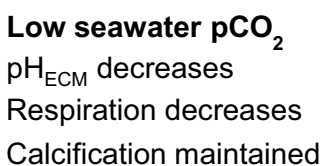

Fig. 4 Summary of key processes affecting $\mathrm{pH}_{\mathrm{ECM}}$ and the impact of the $3{ }^{\circ} \mathrm{C}$ temperature increase on coral physiological processes and $\mathrm{pH}_{\mathrm{ECM}}$. Solutes can be supplied to the ECM either paracellularly, passing along junctions between cells, or transcellularly, passing

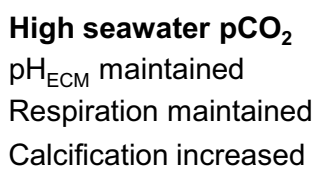

across cells (Allemand et al. 2011). $\mathrm{H}^{+}$(Zoccola et al. 2004) and $\mathrm{HCO}_{3}{ }^{-}$transport (Zoccola et al. 2015) serve to increase and decrease $\mathrm{pH}_{\mathrm{ECM}}$, respectively 
photosynthesis rates (reported in Cole et al. 2018) and either $\left[\mathrm{H}^{+}\right]_{\mathrm{sw}}-\left[\mathrm{H}^{+}\right]_{\mathrm{ECM}}$ or $\mathrm{pH}_{\mathrm{ECM}}$ in any coral colony at either temperature (Supplementary figs. 1 and 2). Further resolution of the relationships between temperature, calcification and metabolism requires observations over a greater range of temperatures (as in Coles and Jokiel 1977).

\section{Implications for coral reefs under future climate change}

This study was conducted under laboratory conditions, and there were no diurnal variations in light availability and seawater DIC chemistry as observed on natural reefs (Dai et al. 2009). Furthermore, we do not know the typical seawater $\mathrm{pH}$ of the reef site in which the corals grew and were acclimated before collection. However, our study yields insights into the likely interactions of seawater $\mathrm{pH}$ and temperature in massive Porites spp. corals. At 750 $\mu$ atm $\mathrm{pCO}_{2}$, calcification rates at $28{ }^{\circ} \mathrm{C}$ exceed those at $25{ }^{\circ} \mathrm{C}$ (Cole et al. 2018) suggesting that temperature increases, below the thermal stress threshold, can at least partially offset the impact of ocean acidification. Future increases in seawater temperatures may offset ocean acidification effects in individuals of this genus living below their upper thermal stress limits. However, elevating seawater temperature beyond the stress threshold reduced both calcification and $\mathrm{pH}_{\mathrm{ECM}}$ in the branching corals Stylophora pistillata and Pocillopora damicornis over a wide range of seawater pH (Guillermic et al. 2021). Thermally induced bleaching may also decrease $\mathrm{pH}_{\mathrm{ECM}}$ (Dishon et al. 2015). Massive Porites spp. are relatively resilient to high seawater $p \mathrm{CO}_{2}$ (Fabricius et al. 2011; Crook et al. 2012) compared to other corals, and the implications of this study for other species are less clear. Temperature had little effect on skeletal $\delta^{11} \mathrm{~B}$ (reflecting $\mathrm{pH}_{\mathrm{ECM}}$ ) in Acropora spp. cultured at ambient and high $\mathrm{pCO}_{2}$ (Reynaud et al. 2004; Dissard et al. 2012) although increasing temperature at high seawater $\mathrm{pCO}_{2}$ acted to significantly decrease calcification in Acropora intermedia (Anthony et al. 2008). While some coral species may acclimatise or adapt to climate change (IPCC 2019), seawater temperature increases are unlikely to benefit the majority of corals which are already living close to their maximum thermal tolerance limits. Coral reefs are predicted to decline greatly at even a $2{ }^{\circ} \mathrm{C}$ temperature increase compared to pre-industrial levels (IPCC 2019).

Supplementary Information The online version contains supplementary material available at https://doi.org/10.1007/s00338021-02170-2.

Acknowledgements This work was supported by the UK Natural Environment Research Council (award NE/I022973/1) to AAF and NA. NERC Scientific Services provided access to the ion microprobe, and we are indebted to Richard Hinton and John Craven (EIMF, University of Edinburgh) for their assistance with the analyses. We thank Dave Steven, Mark Robertson, Casey Perry, Mike Scaboo and Andy Mackie for their assistance with the culture system build. We thank two anonymous reviewers for constructive comments on the first draft of this manuscript.

\section{Declarations}

Conflict of interest On behalf of all authors, the corresponding author states that there is no conflict of interest.

Open Access This article is licensed under a Creative Commons Attribution 4.0 International License, which permits use, sharing, adaptation, distribution and reproduction in any medium or format, as long as you give appropriate credit to the original author(s) and the source, provide a link to the Creative Commons licence, and indicate if changes were made. The images or other third party material in this article are included in the article's Creative Commons licence, unless indicated otherwise in a credit line to the material. If material is not included in the article's Creative Commons licence and your intended use is not permitted by statutory regulation or exceeds the permitted use, you will need to obtain permission directly from the copyright holder. To view a copy of this licence, visit http://creativecommons. org/licenses/by/4.0/.

\section{References}

Al-Horani FA, Al-Moghrabi SM, de Beer D (2003) The mechanism of calcification and its relation to photosynthesis and respiration in the scleractinian coral Galaxea fascicularis. Mar Biol 142:419-426

Allemand D, Tambutté É, Zoccola D, Tambutté S (2011) Coral calcification, cells to reefs Coral reefs: an ecosystem in transition. Springer, pp119-150

Allison N (1996) Geochemical anomalies in coral skeletons and their possible implications for palaeoenvironmental analysis. Mar Chem 55:367-379

Allison N, Cohen I, Finch AA, Erez J, Tudhope AW (2014) Corals concentrate dissolved inorganic carbon to facilitate calcification. Nat Commun 5:1-6

Allison N, Cole C, Hintz C, Hintz K, Rae J, Finch A (2018) The effect of ocean acidification on tropical coral calcification: insights from calcification fluid DIC chemistry. Chem Geol 497:162-169

Allison N, Finch AA, Tudhope AW, Newville M, Sutton SR, Ellam R (2005) Reconstruction of deglacial sea surface temperatures in the tropical Pacific from selective analysis of a fossil coral. Geophys Res Lett 32:L17609. https://doi.org/10.1029/ 2005GL023183

Anthony KRN, Kline DI, Diaz-Pulido G, Dove S, Hoegh-Guldberg O (2008) Ocean acidification causes bleaching and productivity loss in coral reef builders. Proc Natl Acad Sci USA 105:17442-17446

Balan E, Pietrucci F, Gervais C, Blanchard M, Schott J, Gaillardet J (2016) First-principles study of boron speciation in calcite and aragonite. Geochim Cosmochim Acta 193:119-131

Barshis DJ, Ladner JT, Oliver TA, Seneca FO, Traylor-Knowles N, Palumbi SR (2013) Genomic basis for coral resilience to climate change. Proc Natl Acad Sci USA 110:1387-1392

Burton EA, Walter LM (1987) Relative precipitation rates of aragonite and $\mathrm{Mg}$ calcite from seawater - temperature or carbonate ion control. Geology 15:111-114

Cinner J (2014) Coral reef livelihoods. Current Opinion in Environmental Sustainability 7:65-71 
Cohen AL, Layne GD, Hart SR, Lobel PS (2001) Kinetic control of skeletal $\mathrm{Sr} / \mathrm{Ca}$ in a symbiotic coral: Implications for the paleo temperature proxy. Paleoceanography 16:20-26

Cole C, Finch A, Hintz C, Hintz K, Allison N (2018) Effects of seawater pCO 2 and temperature on calcification and productivity in the coral genus Porites spp.: an exploration of potential interaction mechanisms. Coral Reefs 37:471-481

Cole C, Finch A, Hintz C, Hintz K, Allison N (2016) Understanding cold bias: Variable response of skeletal $\mathrm{Sr} / \mathrm{Ca}$ to seawater $\mathrm{pCO}_{2}$ in acclimated massive Porites corals. Scientific Reports 6

Coles SL, Jokiel PL (1977) Effects of temperature on photosynthesis and respiration in hermatypic corals. Mar Biol 43:209-216

Comeau S, Cornwall CE, DeCarlo TM, Doo SS, Carpenter RC, McCulloch MT (2019) Resistance to ocean acidification in coral reef taxa is not gained by acclimatization. Nature Climate Change 9:477-+

Coronado I, Fine M (2019) Bosellini FR (2019) Impact of ocean acidification on crystallographic vital effect of the coral skeleton. Nat Commun 10:2896. https://doi.org/10.1038/s41467-01910833-6

Crook ED, Potts D, Rebolledo-Vieyra M, Hernandez L, Paytan A (2012) Calcifying coral abundance near low-pH springs: implications for future ocean acidification. Coral Reefs 31:239-245

Cuif J-P, Dauphin Y, Doucet J, Salome M, Susini J (2003) XANES mapping of organic sulfate in three scleractinian coral skeletons. Geochim Cosmochim Acta 67:75-83. https://doi.org/10.1016/ S0016-7037(02)01041-4

Cuif J-P, Dauphin Y, Freiwald A, Gautret P, Zibrowius H (1999) Biochemical markers of zooxanthellae symbiosis in soluble matrices of skeleton of 24 Scleractinia species. Comp Biochem Physiol - A Mol Integr Physiol 123:269-278

Dai M, Lu Z, Zhai W, Chen B, Cao Z, Zhou K, Cai W-J, Chen C-TA (2009) Diurnal variations of surface seawater $\mathrm{pCO}(2)$ in contrasting coastal environments. Limnol Oceanogr 54:735-745

DeCarlo TM, D'Olivo JP, Foster T, Holcomb M, Becker T, McCulloch MT (2017) Coral calcifying fluid aragonite saturation states derived from Raman spectroscopy. Biogeosciences 14:5253-5269. https://doi.org/10.5194/bg-14-5253-2017

Dickson AG (1990) Standard potential of the reaction - $\mathrm{AgCl}(\mathrm{S})+1 /$ $2 \mathrm{H}-2(\mathrm{~g})=\mathrm{AG}(\mathrm{s})+\mathrm{HCL}(\mathrm{aq})$ and the standard acidity constant of the ion HSO4- in synthetic sea-water from $273.15-\mathrm{K}$ to 318.15 K. J Chem Thermodyn 22:113-127

Dickson AG, Millero FJ (1987) A comparison of the equilibriumconstants for the dissociation of carbonic-acid in seawater media. Deep-Sea Research Part a-Oceanographic Research Papers 34:1733-1743

Dishon G, Fisch J, Horn I, Kaczmarek K, Bijma J, Gruber DF, Nir O, Popovich Y, Tchernov D (2015) A novel paleo-bleaching proxy using boron isotopes and high-resolution laser ablation to reconstruct coral bleaching events. Biogeosciences 12:5677-5687

Dissard D, Douville E, Reynaud S, Juillet-Leclerc A, Montagna P, Louvat P, McCulloch M (2012) Light and temperature effects on delta B-11 and B/Ca ratios of the zooxanthellate coral Acropora sp.: results from culturing experiments. Biogeosciences 9:4589-4605

Edge SE, Morgan MB, Gleason DF, Snell TW (2005) Development of a coral cDNA array to examine gene expression profiles in Montastraea faveolata exposed to environmental stress. Mar Pollut Bull 51:507-523

Edmunds PJ (2012) Effect of pCO(2) on the growth, respiration, and photophysiology of massive Porites spp. in Moorea. French Polynesia Marine Biology 159:2149-2160

Edmunds PJ, Burgess SC (2016) Size-dependent physiological responses of the branching coral Pocillopora verrucosa to elevated temperature and P-CO2. J Exp Biol 219:3896-3906
Erez J (1978) Vital effect on stable-isotope composition seen in foraminifera and coral skeletons. Nature 273:199-202

Erez J, Reynaud S, Silverman J, Schneider K, Allemand D (2011) Coral Calcification Under Ocean Acidification and Global Change

Fabricius KE, Langdon C, Uthicke S, Humphrey C, Noonan S, De'ath G, Okazaki R, Muehllehner N, Glas MS, Lough JM (2011) Losers and winners in coral reefs acclimatized to elevated carbon dioxide concentrations. Nat Clim Chang 1:165-169

Falini G, Fermani S, Goffredo S (2015) Coral biomineralization: A focus on intra-skeletal organic matrix and calcification. Semin Cell Dev Biol 46:17-26

Foster GL (2008) Seawater pH, PCO2 and CO32- variations in the Caribbean Sea over the last $130 \mathrm{kyr}$ : A boron isotope and $\mathrm{B} / \mathrm{Ca}$ study of planktic forminifera. Earth Planet Sci Lett 271:254-266

Foster GL, Hoenisch B, Paris G, Dwyer GS, Rae JWB, Elliott T, Gaillardet J, Hemming NG, Louvat P, Vengosh A (2013) Interlaboratory comparison of boron isotope analyses of boric acid, seawater and marine $\mathrm{CaCO} 3$ by MC-ICPMS and NTIMS. Chem Geol 358:1-14

Foster G, Pogge von Strandmann PA, Rae J (2010) Boron and magnesium isotopic composition of seawater. Geochemistry, Geophysics, Geosystems 11

Gabitov RI, Rollion-Bard C, Tripati A, Sadekov A (2014) In situ study of boron partitioning between calcite and fluid at different crystal growth rates. Geochim Cosmochim Acta 137:81-92. https://doi.org/10.1016/j.gca.2014.04.014

Gast JA, Thompson TG (1959) Evaporation of boric acid from sea water. Tellus 11:344-347

Gattuso JP, Lavigne H (2009) Technical Note: Approaches and software tools to investigate the impact of ocean acidification. Biogeosciences 6:2121-2133

Guillermic M, Cameron LP, De Corte I, Misra S, Bijma J, de Beer D, Reymond CE, Westphal H, Ries JB, Eagle RA (2021) Thermal stress reduces pocilloporid coral resilience to ocean acidification by impairing control over calcifying fluid chemistry. Sci Adv 7:eaba9958

Holcomb M, DeCarlo TM, Gaetani GA, McCulloch M (2016) Factors affecting $\mathrm{B} / \mathrm{Ca}$ ratios in synthetic aragonite. Chem Geol 437:67-76

IPCC (2014) Climate Change 2013: The Physical Science Basis

IPCC (2019) Special Report on the Ocean and cryosphere in a changing climate

Ihli J, Clark JN, Kanwal N, Kim Y-Y, Holden MA, Harder RJ, Tang CC, Ashbrook SE, Robinson IK, Meldrum FC (2019) Visualization of the effect of additives on the nanostructures of individual bio-inspired calcite crystals. Chem Sci 10:1176-1185. https://doi.org/10.1039/C8SC03733G

Ip YK, Lim ALL, Lim RWL (1991) Some properties of calciumactivated adenosine-triphosphatase from the hermatypic coral Galaxea-fascicularis. Mar Biol 111:191-197

Kakihana H, Kotaka M, Satoh S, Nomura M, Okamoto M (1977) Fundamental studies on the ion-exchange separation of boron isotopes. Bull Chem Soc Jpn 50:158-163

Kasemann SA, Schmidt DN, Bijma J, Foster GL (2009) In situ boron isotope analysis in marine carbonates and its application for foraminifera and palaeo-pH. Chem Geol 260:138-147

Kellock C, Cole C, Penkman K, Evans D, Kroger R, Hintz C, Hintz K, Finch A, Allison N (2020) The role of aspartic acid in reducing coral calcification under ocean acidification conditions. Sci Rep. https://doi.org/10.1038/s41598-020-69556-0

Kenkel CD, Meyer E, Matz MV (2013) Gene expression under chronic heat stress in populations of the mustard hill coral (Porites astreoides) from different thermal environments. Mol Ecol 22:4322-4334 
Klochko K, Cody GD, Tossell JA, Dera P, Kaufman AJ (2009) Reevaluating boron speciation in biogenic calcite and aragonite using 11B MAS NMR. Geochim Cosmochim Acta 73:1890-1900

Klochko K, Kaufman AJ, Yao W, Byrne RH, Tossell JA (2006) Experimental measurement of boron isotope fractionation in seawater. Earth Planet Sci Lett 248:276-285

Kurihara H, Takahashi A, Reyes-Bermudez A, Hidaka M (2018) Intraspecific variation in the response of the scleractinian coral Acropora digitifera to ocean acidification. Marine Biology 165

Lee K, Kim T-W, Byrne RH, Millero FJ, Feely RA, Liu Y-M (2010) The universal ratio of boron to chlorinity for the North Pacific and North Atlantic oceans. Geochim Cosmochim Acta 74:1801-1811

Maor-Landaw K, Karako-Lampert S, Ben-Asher HW, Goffredo S, Falini G, Dubinsky Z, Levy O (2014) Gene expression profiles during short-term heat stress in the red sea coral Stylophora pistillata. Glob Change Biol 20:3026-3035

Mass T, Giuffre AJ, Sun C-Y, Stifler CA, Frazier MJ, Neder M, Tamura N, Stan CV, Marcus MA, Gilbert PUPA (2017) Amorphous calcium carbonate particles form coral skeletons. Proc Nat Acad Sci 114:E7670-E7678. https://doi.org/10.1073/ pnas. 1707890114

Mehrbach C, Culberson CH, Hawley JE, Pytkowicz RM (1973) Measurement of apparent dissociation-constants of carbonic-acid in seawater at atmospheric-pressure. Limnol Oceanogr 18:897-907

Mollica NR, Guo W, Cohen AL, Huang K-F, Foster GL, Donald HK, Solow AR (2018) Ocean acidification affects coral growth by reducing density. Proc Nat Acad Sci. https://doi.org/10.1073/ pnas. 1712806115

Nir O, Vengosh A, Harkness JS, Dwyer GS, Lahav O (2015) Direct measurement of the boron isotope fractionation factor: Reducing the uncertainty in reconstructing ocean paleo-pH. Earth Planet Sci Lett 414:1-5

Noireaux J, Mavromatis V, Gaillardet J, Schott J, Montouillout V, Louvat P, Rollion-Bard C, Neuville D (2015) Crystallographic control on the boron isotope paleo-pH proxy. Earth Planet Sci Lett 430:398-407

Rae JWB, Foster GL, Schmidt DN, Elliott T (2011) Boron isotopes and $\mathrm{B} / \mathrm{Ca}$ in benthic foraminifera: Proxies for the deep ocean carbonate system. Earth Planet Sci Lett 302:403-413

Reynaud S, Hemming NG, Juillet-Leclerc A, Gattuso J-P (2004) Effect of pCO 2 and temperature on the boron isotopic composition of the zooxanthellate coral Acropora sp. Coral Reefs 23:539-546

Rollion-Bard C, Blamart D, Trebosc J, Tricot G, Mussi A, Cuif J-P (2011) Boron isotopes as pH proxy: a new look at boron speciation in deep-sea corals using 11B MAS NMR and EELS. Geochim Cosmochim Acta 75:1003-1012

Ross CL, DeCarlo TM, McCulloch MT (2019) Environmental and physiochemical controls on coral calcification along a latitudinal temperature gradient in Western Australia. Glob Change Biol 25:431-447

Schoepf V, Jury CP, Toonen RJ, McCulloch MT (2017) Coral calcification mechanisms facilitate adaptive responses to ocean acidification. Proceedings of the Royal Society b: Biological Sciences 284:20172117

Sen S, Stebbins J, Hemming N, Ghosh B (1994) Coordination environments of $\mathrm{B}$ impurities in calcite and aragonite polymorphs: a 11B MAS NMR study. Am Miner 79:819-825

Sevilgen DS, Venn AA, Hu MY, Tambutté E, de Beer D, PlanasBielsa V, Tambutté S (2019) Full in vivo characterization of carbonate chemistry at the site of calcification in corals. Science advances 5:eaau 7447

Szmant AM (2002) Nutrient enrichment on coral reefs: Is it a major cause of coral reef decline? Estuaries 25:743-766

Uppstrom L (1974) The boron/chlorinity ratio of deep-sea water from the Pacific Ocean. Deep Sea Res 21:161-162

Van Heuven S, Pierrot, D., Rae J.W.B, Lewis, E. \& Wallace D.W.R.. (2011) MATLAB Program Developed for CO2 System Calculations. ORNL/CDIAC-105b, Carbon Dioxide Information Analysis Center, Oak Ridge National Laboratory, U.S., Department of Energy, Oak Ridge, Tennessee. 2011.

Venn AA, Bernardet C, Chabenat A, Tambutté E, Tambutté S (2020) Paracellular transport to the coral calcifying medium: effects of environmental parameters. J Exp Biol. https://doi.org/10.1242/ jeb. 227074

Venn AA, Tambutte E, Holcomb M, Laurent J, Allemand D, Tambutte S (2013) Impact of seawater acidification on $\mathrm{pH}$ at the tissue-skeleton interface and calcification in reef corals. Proc Natl Acad Sci USA 110:1634-1639

Venn AA, Tambutte E, Caminiti-Segonds N, Techer N, Allemand D, Tambutte S (2019) Effects of light and darkness on $\mathrm{pH}$ regulation in three coral species exposed to seawater acidification. Scientific Reports 9

Veron JEN (1993) Corals of Australia and the Indo-pacific. University of Hawaii Press

Wolthers M, Nehrke G, Gustafsson JP, Van Cappellen P (2012) Calcite growth kinetics: Modeling the effect of solution stoichiometry. Geochim Cosmochim Acta 77:121-134

Yuan X, Yuan T, Huang H, Jiang L, Zhou W, Liu S (2018) Elevated $\mathrm{CO} 2$ delays the early development of scleractinian coral Acropora gemmifera. Scientific Reports 8

Zoccola D, Ganot P, Bertucci A, Caminiti-Segonds N, Techer N, Voolstra CR, Aranda M, Tambutte E, Allemand D, Casey JR, Tambutte S (2015) Bicarbonate transporters in corals point towards a key step in the evolution of cnidarian calcification. Scientific Reports. https://doi.org/10.1038/srep09983

Zoccola D, Innocenti A, Bertucci A, Tambutte E, Supuran CT, Tambutte S (2016) Coral carbonic anhydrases: regulation by ocean acidification. Marine Drugs 14:109

Zoccola D, Tambutte E, Kulhanek E, Puverel S, Scimeca JC, Allemand D, Tambutte S (2004) Molecular cloning and localization of a PMCA P-type calcium ATPase from the coral Stylophora pistillata. BBA-Biomembranes 1663:117-126

Publisher's Note Springer Nature remains neutral with regard to jurisdictional claims in published maps and institutional affiliations. 